\title{
Hominid exploitation of the environment and cave bear populations. The case of Ursus spelaeus Rosenmüller-Heinroth in Amutxate cave (Aralar, Navarra-Spain)
}

\author{
Trinidad Torres $^{\mathrm{a}, *}$, José E. Ortiz ${ }^{\mathrm{a}}$, Rafael Cobo ${ }^{\mathrm{b}}$, Pedro de $\mathrm{Hoz}^{\mathrm{c}}$, \\ Ana García-Redondo ${ }^{\mathrm{c}}$, Rainer Grün ${ }^{\mathrm{d}}$ \\ ${ }^{a}$ Biomolecular Stratigraphy Laboratory, E.T.S.I. Minas, Universidad Politécnica de Madrid, C/Ríos Rosas 21 , E-28003 Madrid, Spain \\ ${ }^{\mathrm{b}}$ CEDEX, Po Bajo Virgen del Puerto, E-28005 Madrid, Spain \\ ${ }^{\mathrm{c}}$ I.E.S. Rafael Alberti, C/Virgen de la Cabeza s/n. E-28820 Madrid, Spain \\ ${ }^{\mathrm{d}}$ Research School of Earth Sciences, Jaeger OHB-B, Building 61B, Australian National University, Canberra ACT200, Australia
}

\begin{abstract}
Cave bears (Ursus deningeri and U. spelaeus) and hominids (Homo heidelbergensis, H. neanderthalensis, and H. sapiens) were potential competitors for environmental resources (subterranean and open air). Here, we examined the age at death of cave bear (Ursus spelaeus Rosenmiiller-Heinroth) specimens from Amutxate cave in order to shed light on the effect of resource sharing between cave bears and hominids. After studying dental wear of the deciduous and permanent dentitions, the ontogenetic development of mandibles, and incremental layers of cement (annuli), we defined five age groups differentiated by marked development and size gaps. Our findings indicate that after hibernating, bears abandoned the den, thereby leaving the subterranean environment (caves) free for temporary hominid occupation-this would explain the subtle traces of hominid presence in many dens. However, a simple calculation based on age at death of subadult and adult cave bear specimens in Amutxate cave, extrapolated to the whole cave area, showed that the area surrounding this cave hosted bears for at least 9,000 years. This length of habitation, quite similar to the time-span derived from amino acid racemization and electron spin resonance, indicates that bear populations in the Amutxate cave constituted a serious constraint for hominid exploitation of the environment.
\end{abstract}

\section{Introduction}

Fossilized bones and teeth of bears (Ursus deningeri von Reichenau and Ursus spelaeus Rosenmüller-Heinroth) are commonly found in caves. In some cases, caves also show weak evidence of hominid presence in the form of low numbers of herbivore bones and teeth, and stone tools. On occasion, evidence of human presence is stronger, where stone tools and hominid remains are found in general stratigraphic association.

From Middle Pleistocene to Upper Pleistocene times, at least three species of hominids (Homo heidelbergensis, H. neanderthalensis, and $H$. sapiens) coexisted with hibernating cave bears ( $U$. deningeri and $U$. spelaeus) in the Iberian Peninsula. This coexistence implies that bears and hominids competed for habitat. This competition was mostly passive-Pleistocene cave bears were vegetarian (i.e., they did not hunt hominids; Bocherens et al., 1990, 1991; Fernández-Mosquera, 1998), and hominids did not usually eat bears. In a study that attempted to differentiate between predation-mediated and hibernation-related cave bear 
( $U$. deningeri) mortality in Yarimburgaz Cave in Turkey, Stiner (1998) concluded that the non-violent (hibernation-related) attrition pattern dominated. Torres et al. (1991) reported similar patterns of bear death assemblages in many Spanish caves.

Earlier evidence of hominid predation of cave bears has recently been reinterpreted. For example, the bear skull fragment found in Sloup Cave in Moravia (Czech Republic) (see Kurtén, 1976) was previously argued to be clear proof of a single bear hunted by humans. This was proved false, however, when the flint fragment that was found near the fossil (Hitchcock, 2005) was shown not to be a spearhead as reported by Bächler (1940). In another example, the site of Erd (Hungary) was previously described (Gabori-Csánk, 1968) as an open-air camp of cave bear hunters. However, whole bear skeletons were found at the site, and it is implausible that whole bear corpses were transported to the top of the hill. In fact, a careful reading of the site description reveals that Erd Hill was a cave whose roof is now missing, suggesting that the bear death assemblage resulted from hibernation-related deaths, not predation. Similar objections are voiced by Pinto-Llona et al. (2005).

Starvation is, and probably was, the main cause of death during hibernation. According to many authors, both sexes of cave bears die during hibernation (Koby, 1949; Kurtén, 1976; Torres, 1984; Grandal d' Anglade and Vidal-Romaní, 1997), and a balanced number of males and females are usually found in caves, although not necessarily in the same caves at the same time. During hibernation, bears change their metabolism in order to reduce their energy requirements. This strategy involves switching to a "lipid diet" without protein consumption, using body fats as a source of energy. To protect the liver during hibernation, bears do not excrete but reabsorb urea from the bladder (Crombie et al., 1993).

In forced summer starvation (Nelson et al., 1975), fat and protein are used as a source of energy, and the nitrogenous waste products of amino acids are excreted in urine and feces (Lyman et al., 1982). Thus, undernourishment during the fall due to competition, environmental stress, or disease would threaten bear survival. For comparative purposes, we have included a summary of some of the basic ecological characteristics of modern hibernating bears (Table 1).

While there were many threats to cave bear survival, cave bears also posed a great threat to Pleistocene hominid groups. Hominid activities such as sheltering, hunting, scavenging, and gathering were probably restricted by wandering cave bears in search of food (scavenging, gathering) or mating partners. The "minimal period of country occupation," calculated by determining the age at death of subadult and adult cave bears, helps to establish this period of restricted hominid transit. In some cases, hominids moved into the uplands in pursuit of wild goat (Capra ibex L.) herds. They killed goat adults and kids born at the spring break-up after the thaw, as is evident from the deciduous dentitions and unfused epiphyses of the goat assemblages in the caves of El Reguerillo (Torres, 1974) and Amutxate. These findings suggest that by the beginning of the spring, shelters had been abandoned by cave bears and taken over by hominid groups.

Calculating the age at death of cave bear cubs enables us to determine when females and their offspring abandoned the cave. Subterranean shelters would have been more useful to predatory hominid groups if they had become vacant at the end of winter or beginning of spring. Extended use of caves by bears would have prevented hominid use of these shelters and a wide area around it. Thus, the age at death of cave bears provides information on the constraints on the geographical dispersion and environmental exploitation of hominid groups. With this information, it is possible to establish a theoretical calendar of intermittent cave availability for temporal hominid camps. In this study, we analyze the

Table 1

Ecological data on living species of hibernating bears

\begin{tabular}{|c|c|c|c|}
\hline & Ursus arctos & Ursus maritimus & Ursus americanus \\
\hline Mating & May-July (Wilson and Ruff, 1999) & April-May (Ramsay and Stirling, 1986) & $\begin{array}{l}\text { June-July (Wimsatt, 1963) } \\
\text { June-August (Stirling, 1993) }\end{array}$ \\
\hline Den entrance & $\begin{array}{l}\text { October-December (Camarra, 1987; } \\
\text { Wilson and Ruff, 1999) }\end{array}$ & October-December (Amstrup, 1995) & $\begin{array}{l}\text { late December to early January } \\
\text { (Johnson, 1978) }\end{array}$ \\
\hline Den leaving & $\begin{array}{l}\text { March-May (Wilson and Ruff, 1999) } \\
\text { April (Ward, 1994) }\end{array}$ & late March to mid-April (Amstrup, 1995) & $\begin{array}{l}\text { late March to early April } \\
\text { (Johnson, 1978) }\end{array}$ \\
\hline Birth & $\begin{array}{l}\text { January-March (Wilson and Ruff, 1999) } \\
\text { January-February (Clevenger and Purroy, 1991) }\end{array}$ & January (Uspenski, 1977) & $\begin{array}{l}\text { early January to early February } \\
\text { (Alt, 1983) }\end{array}$ \\
\hline Weaning & 18-30 months (Wilson and Ruff, 1999) & 27 months (Stirling, 1986) & 17-18 months (Needham, 2000) \\
\hline Interbirth interval & $\begin{array}{l}\text { 2-4 years (Wilson and Ruff, 1999) } 3 \text { years } \\
\text { (Clevenger and Purroy, 1991). Linked to } \\
\text { primary productivity and population density } \\
\text { (Ferguson and McLoughlin, 2000) }\end{array}$ & 3 years (Stirling, 1986) & $1-2$ years \\
\hline Sexual maturity & 4-6 years (Wilson and Ruff, 1999) & 3 years (Lentfer and Miller, 1969) & $\begin{array}{l}\text { 1-4 years (females) and } 4-5 \text { years } \\
\text { (males) (Stirling, 1993) }\end{array}$ \\
\hline $\begin{array}{l}\text { Survival rate of } \\
\text { cubs and yearlings }\end{array}$ & & $44-53 \%$ (Amstrup, 1995) & $75 \%$ (Kolenosky, 1990) \\
\hline
\end{tabular}


cave bear remains in Amutxate cave in order to determine possible constraints affecting hominid exploitation of the environment.

\section{Materials and methods}

Amutxate cave (longitude $1^{\circ} 58^{\prime} 1^{\prime \prime} \mathrm{W}$; latitude $42^{\circ} 58^{\prime} 25^{\prime \prime} \mathrm{N}$, Fig. 1) was discovered in 1988 by members of the Satorrak Speleological Group. Pristine cave bear remains covered the entire surface of a large hall $\left(650 \mathrm{~m}^{2}\right)$. The site consists of two separate areas: the upper part is a flat area where cave bear ancient nests are still visible; the lower part is a gently sloped sediment ramp with cave bear remains scattered at its foot. There is a narrow sinkhole through which subterranean runoff transports mud, gravel, and severely damaged cave bear remains during rainy periods. A recent debris-cone overlying the lower part of the hall and a gigantic roof collapse at its uppermost tip make this cave unavailable for further hibernating purposes.

Five excavation seasons were conducted by one of the authors (T.T.). Bear remains from $401 \times 1 \mathrm{~m}$-squares (Fig. 2) were unearthed from a $25 \mathrm{~cm}$-thick bone bed. Total recovery of fossil remains was achieved through water-washing-sieving of the sediment at $0.5 \mathrm{~mm}$ screen size. With dates obtained through amino acid racemization (on dentine), uranium/thorium analyses (on fallen stalactites included in the bone-bearing sediment), and electron spin resonance (ESR) (on canine enamel), it was established that the cave was inhabited between 39,000 and 48,000 BP (i.e., during the 3rd MIS; Torres et al., 2002). Of the approximately 17,000 large mammal bones and teeth recovered, only 39 belong to mammals other than cave bears ( 7 from Arctiodactyla and 32 from small carnivores). Only four lithic artifacts were recovered, suggesting that human presence in the cave was not substantial.

To determine the age at death of cave bears from Amutxate cave, we analyzed 232 mandibles ( 67 adults, 157 cubs, and 8 newborns), 316 lower deciduous molars, and 564 adult lower premolars and molars. For comparative purposes, we included well-preserved mandibles from other localities [La Lucia cave (U. spelaeus), Saldarrañao cave (U. arctos), and Cueva Nueva ( $U$. deningeri); see Fig. 1]. We used four types of analyses to determine age at death: 1) wear stage and root resorption of the lower deciduous molar (also known as the "carnassial," or dp4); 2) wear stage and root development in adult lower premolars and molars; 3 ) cement layer counts of the first lower molar; and 4) ontogenetic development of the mandible on the basis of size and bone texture. The following sections describe these analyses in more detail.

\section{Deciduous dentition-wear and root resorption}

Previous research has cited cases of worn deciduous dentition in the cave bear (Koby, 1949, 1952) and in tremarctines from South America (Soibelzon and Carlini, 2003). Andrews and Turner (1992) used deciduous canine wear analysis to outline the behavioral patterns of the cave bear ancestor $(U$. deningeri von Reichenau) population from Westbury cave (England).

In this study, we analyzed the wear stage (worn/unworn) on 316 lower "carnassial" teeth of the deciduous dentition following Terzea's numbering system (dp4, Terzea, 1969) and using the naked eye and a magnifying lens $(10 \times 50)$. When possible, root development was recorded. Fully developed roots and strongly resorbed roots were differentiated. All dp4s were found disarticulated from their mandibles; therefore, we could not distinguish between shed and unshed dp4s, although the presence of roots in unworn teeth usually corresponded to unshed dp4s. Teeth with totally resorbed roots that were generally worn corresponded to shed or almost shed dp4s.

\section{Permanent dentition-wear and root development}

Many studies have addressed age estimation using dental wear (Kurtén, 1958; Dittrich, 1960; Torres, 1976, 1984;

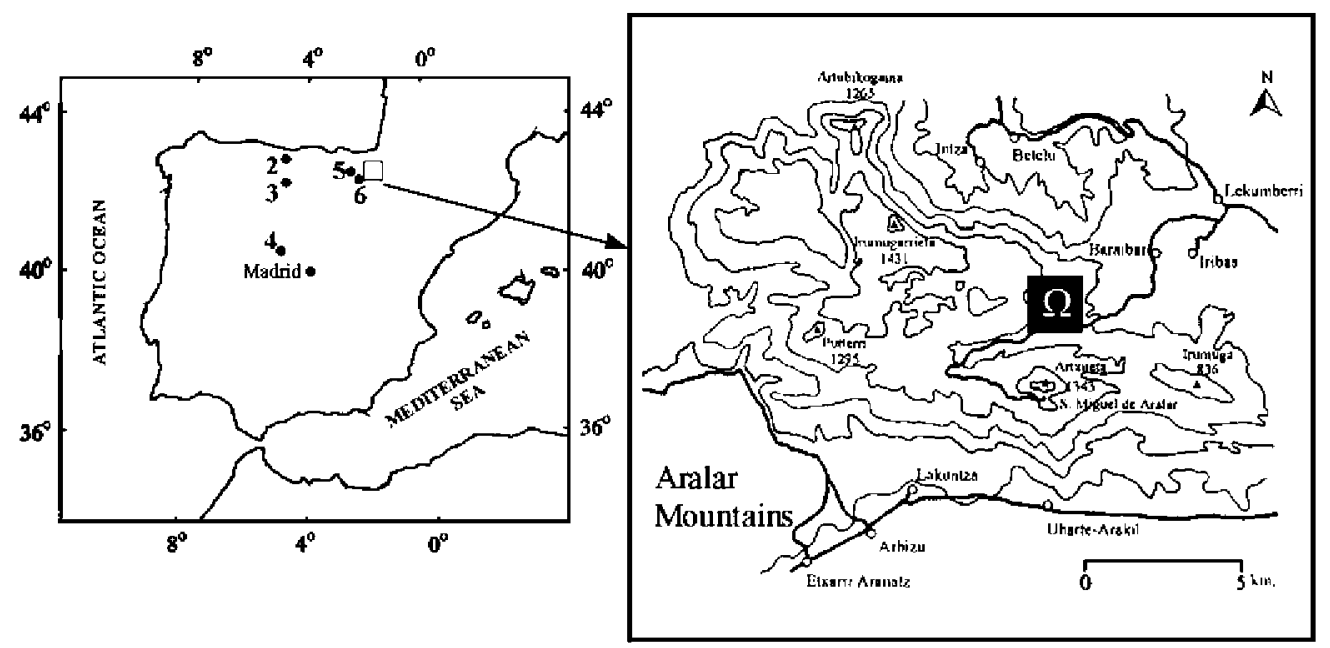

Fig. 1. Geographic location of Amutxate cave and other caves with bear remains used in this study. (1): Amutxate cave ( $U$. spelaeus, Aralar, Navarra); (2) La Lucia cave (U. spelaeus, Quintanilla, Cantabria); (3) Saldarrañao cave (U. arctos Espinosa de los Monteros, Burgos); (4) Cueva Nueva (U. deningeri, Pedraza, Segovia); (5) Troskaeta cave (U. spelaeus parvilatipedis, Ataun, Guipúzcoa); (6) Eulatz cave (U. spelaeus, Aralar, Navarra). 


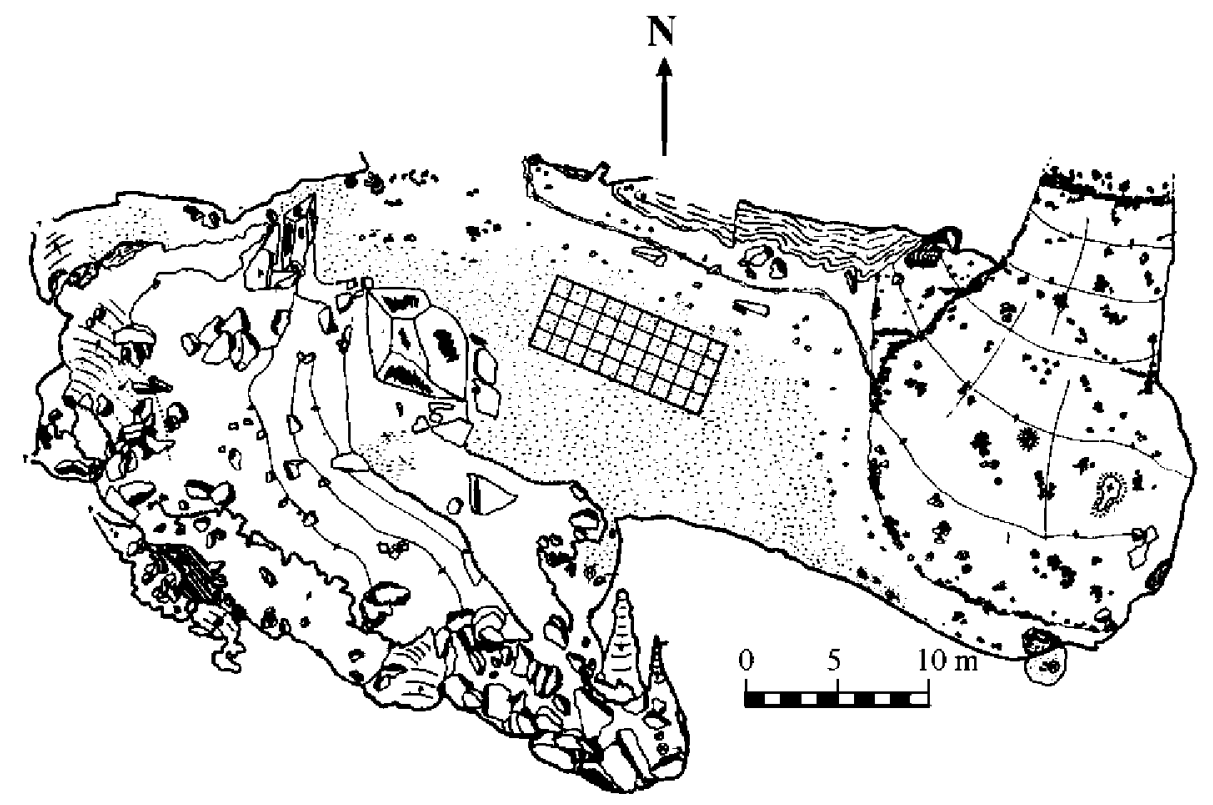

Fig. 2. Map of the excavated area in Amutxate cave. Forty $1 \times 1 \mathrm{~m}$ squares were excavated. Map provided by Satorrak Speleological Group.

Andrews and Turner, 1992; Grandal d'Anglade, 1993; Gargett, 1996; Grandal d'Anglade and Vidal-Romaní, 1997; Stiner, 1998). In the present study, we added observation of root development, which is related to the ontogenetic development of the housing mandible.

Four wear degrees were defined following the classes described by Musil (1965) and Torres $(1976,1984)$. These categories match those defined by Stiner (1998). The four dental wear group (DWG) stages were easily identified after observation of the occlusal area of premolar and molar crowns:

DWG I: Premolars and molars are unworn or slightly worn. The enamel is fully preserved, although small abrasion facets can be identified under a lower power stereomicroscope.

DWG II: Premolars and molars are worn. The abrasion facets reach the tip of the cusps. In some cases, dentine is visible at the bottom of concave, circular, or elliptically contoured, abraded zones.

DWG III: Premolars and molars are severely damaged. Enamel persists in the flattest parts of the occlusal area of the crown and on the labial and lingual walls.

DWG IV: Enamel has been removed from more than half of the occlusal area of the cheek teeth. Tooth damage can vary from moderate to extreme. In cases of extreme wear, there is a total loss of enamel, and profound wear troughs at the occlusal area reach the pulp cavity. On the anterior and posterior tips of the teeth, deep interdental wear facets appear.

Four root development group (RDG) stages were established: RDG I, poorly developed roots $(<30 \%)$; RDG II, half developed roots (50\%); RDG III, nearly fully developed roots with open apices (90\% development); and RDG IV, fully developed roots with closed apices (100\% development).

\section{Cement layer counts}

Counting cement growth layers (annuli) is a precise method of determining age at death. Several studies have applied this technique to establish the age of living black ( $U$. americanus Pallas) and brown (U. arctos Linnaeus) bears (e.g., Stoneberg and Jonkel, 1966; Klevezal and Kleinenberg, 1967; Craighead et al., 1970; Wiley, 1974; Stallibrass, 1982) and cave bear remains (Breuer, 1931; Debeljak, 1996a).

Here, we examined the first lower molar because it is the first to erupt (earliest cement generation) and wear out. Eruption timing of this molar is well known in the brown bear ( $U$. arctos Linnaeus), and the process can be observed in a large number of well-preserved mandibles from newborn, yearling, and subadult representatives from Amutxate cave. However, the true timing of the appearance of this molar is still unknown in cave bears. In many mandibles from very young cave bear specimens, these molars have fallen out because of the limited development of the bone-root connective tissue (cement); in very old representatives, this molar may be absent because of in-vivo avulsion due to pathological conditions affecting root, alveoli, or both (Pérez et al., 1986). According to our data, this molar is lost in $15 \%$ of mandibles of very old bears (Torres, 1984).

We examined a set of 28 first lower molars corresponding to isolated individuals, and 4 lower molars from mandibles were studied by x-ray. The samples were chosen mainly to establish the age at death of very old individuals (of a total of 25 deeply worn lower first molars, 12 were analyzed), while some sets of samples were from intermediate age representatives.

Studies of modern bear dentitions use demineralization and histological preparation. However, because fossil teeth are 
subjected to continuous weathering of both inorganic (65$70 \%)$ and organic $(35-30 \%)$ constituents of the cement (Scott and Symons, 1974; Osborn, 1981; Hillson, 1986), these methods are inappropriate here. We applied the method of Debeljak (1996a) that does not require previous root demineralization: the root section was polished and etched with a $20 \%$ orthophosphoric acid $\left(\mathrm{H}_{3} \mathrm{PO}_{4}\right)$ solution and then stained with gentianae violet $(5 \%)$. The samples were observed under a $\mathrm{Ni}$ kon stereomicroscope at low magnification $(25-50 \times)$, photographed in a Leitz Orthophot microscope, and some of the youngest specimens were analyzed under an environmental scanning electron microscope (ESEM) to observe root development.

\section{Ontogenetic development of the mandible}

Several studies have addressed the ontogenetic development of the cave bear skeleton (Breuer, 1931; Debeljak, 1996b). Moreover, the use of modern brown bear development as an analog for cave bear development has received much attention. In many cases, the calendar of eruption/loss of deciduous and permanent teeth has been established from zoo samples in which "ecological" conditions differ greatly from those in the wild (e.g., bears do not hibernate in zoos).

Although our study included a large sample of mandibles, the number of well-preserved mandibles from very young specimens was low. We analyzed: 1) deciduous teeth alveoli, 2) development and positioning of permanent teeth alveoli and germs, 3) degree of wear of erupted cheek teeth, and 4) bone surface texture. Several radiographs were also taken to confirm the distribution of alveoli and the position of partially erupted or unerupted teeth. Bone surface texture was studied through a stereomicroscope, and three samples were examined by ESEM.

Five discrete groups of mandibular ontogenetic development (MDG I to V) were identified, taking into account the possible effect of sexual dimorphism. This discontinuous size distribution was already observed by Eheremberg (1931). Because mandibles observed with the naked eye present different external textures, we also observed them through
ESEM. For this purpose, mandibular fragments with different ontogenetic development (MDG II, MDG III, MDG V) were used. The following are descriptions of the mandibular development groups used in the study:

MDG I: Diminutive (rat-sized) mandibles that are never recovered intact during excavation. Thin-walled, bony flakes with porous texture and partially preserved alveoli indicate that they correspond to newborn cave bears.

MDG II: Small (fox-sized) mandibles [not cited in Kurtèn (1976)] have erupted and unworn deciduous dentition. Permanent incisors, canines, and lower carnassials appear in germ state. The bone surface texture is rough and porous (Fig. 3A), and these textures can be distinguished in Debeljak (1996b, plates 1, 2, and 3) and Eheremberg (1931, Taf. CXX Figs. 1, 2).

MDG III: Small to medium (wolf- and hyena-sized) mandibles have M1 erupted and the M2 and P4 main cusps extending out through the gums; M3 is in sub-vertical arrangement. In MDG III bones (Fig. 3B), due to the ossification process (Beaupre et al., 2000) cartilaginous regions may persist within the osseous traveculae, which are responsible for the aforementioned texture and appearance (Francillon-Vieillot et al., 1990). Tumarkin-Deratzian (2003) produced analogous results after analyzing the bone-surface textures of extant and fossil archosaurs.

MDG IV: Medium (lion-sized) mandibles have the canine and all the cheek teeth fully erupted (M3 in occlusion). All of the cheek teeth show little occlusal wear. This size must not be mistaken for small mandibles of the adult female cave bear, which are larger.

MDG V: Adult mandibles that includes both larger (male) and smaller (female) mandibles; usually, all the molars are worn. The mandible textures are shown in Figure $3 \mathrm{C}$.
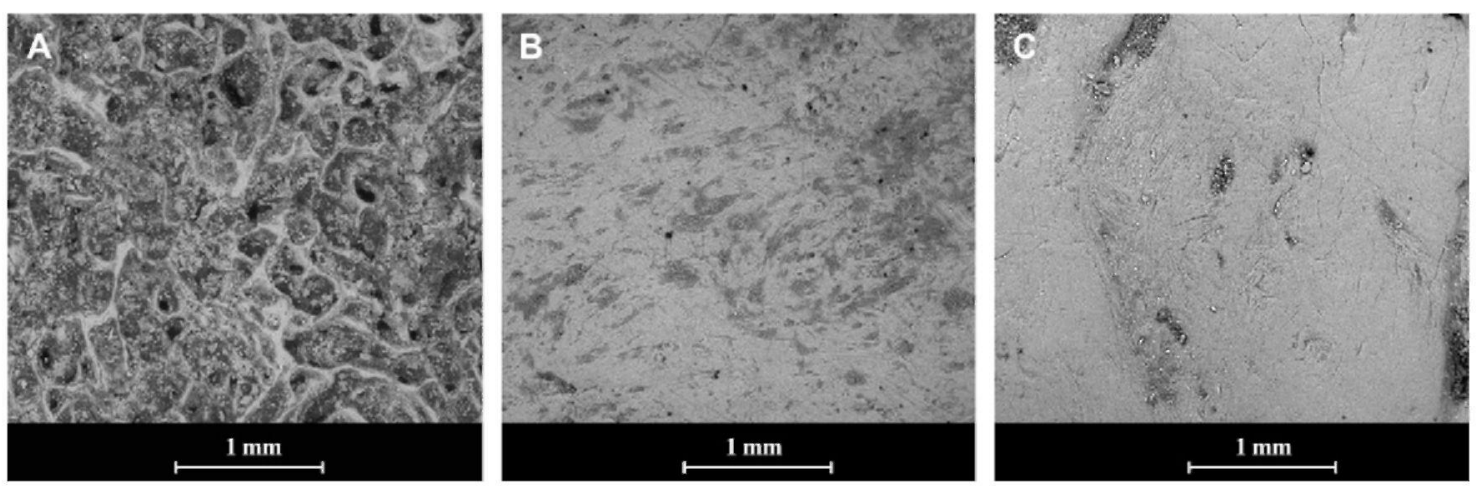

Fig. 3. ESEM images from bone surface textures of cave bear mandibles with distinct stages of ontogenetic development from Amutxate cave. (A) From a mandible of MDG II group; (B) from a mandible of MDG III group; (C) from a mandible of MDG V group. Samples were taken from identifiable fragments of mandibles at the rear of the canine alveolus. Sample A corresponds to the AX-3104 mandible and was obtained by drilling the mandibular body with a hollow diamond device. 


\section{Results and discussion}

\section{Deciduous dentition-wear and root resorption}

In the $\mathrm{dp} 4$, wear affected the tip of the protoconid, and sometimes the posterior crests of the protoconid and metaconid were also affected (Fig. 4). Some hypoconids were also worn. The worn areas appeared as elliptically shaped depressions.

Two groups of deciduous carnassial carriers were identified (Table 2): the first had partially rooted and unworn molars, and the second had totally resorbed roots and worn enamel.

\section{Permanent dentition-wear and root development}

The frequencies of the wear stages of the lower premolars and molars are shown in Table 3, and root development group frequencies are presented in Table 4.

About $40 \%$ of all lower premolars and molars had fully developed roots. Considering only premolars and molars with open roots (Table 4 , italics and parenthesis), we observed the typical spectrum of root development in cheek teeth: P4 (RDG I + RDG II: 88\%); M1 (RDG III: 87\%); M2 (RDG II: $81 \%$ ); and M3 (RDG I: 90\%).

On the basis of degree of wear of the first lower molar, we propose that the largely dominant first lower molars in stage DWG I correspond to bear cubs. Similarly, Debeljak (1996b) considered these mandibles to correspond to five- to sevenmonth-old bear cubs. Some first lower molars of this wear group showed Retzius bands visible to the naked eye. Teeth from mandibles of RDG I and RDG II representatives belonged to DWG I.

The first upper and lower molars showed the highest frequency of DWG III and RDG IV stages, reflecting their early eruption time. The high frequency of low wear cases in the third lower molars can be explained because they were vertically implanted in an extremely shallow alveolus behind the vertical ramus of the mandible. These molars rotate and move inferiorly during ontogeny to occupy their final position in the posterior tooth row. According to Dittrich (1960), the eruption of lower fourth premolars and first molars is synchronized in the brown bear ( $U$. arctos Linnaeus). In a small sample, Andrews and Turner (1992) found that the frequency of "mature" lower molars was also higher.

\section{Counting of cement annuli}

Counting of cement incremental layers provides the required accuracy for age at death determination (Table 5, Fig. 5). Under the ESEM, the polished sections of the roots of the first lower molars showed two clearly distinct concentric zones. The dentine appeared as a darker area where a radial structure was barely distinguishable. The outer part of the root showed a light grey ring: the cement.

A complete cement ring consists of a wide, brightly dyed ring surrounding a thin, dark annulus. When only the bright part of a cement ring was developed, we considered it to be half an annulus (0.5). Typically, the first four to five annuli are wider than the later ones, indicating a fast cement accretion to connect the roots to alveoli walls. When the individual growth process ends, the accretional bands begin to get thinner, making their identification and counting more difficult. If we establish a parallel with the brown bear (Wilson and Ruff, 1999), cave bear sexual maturity was reached at the age of four to six years. In the polar bear, sexual onset occurs at the age of three years (Mundy and Fuller, 1964; Lentfer and Miller, 1969; Craighead et al., 1970). In the cement annuli analysis of Amutxate cave remains, we found that the first four to five annuli were thicker than the remaining ones.

All the first lower molars with closed roots and heavily worn enamel (RDG IV and DWG IV) corresponded to old bears (10-19 annuli). The molars with fully closed root apices (RDG IV) and slight enamel wear (DWG II) had a fully developed annulus (two bands were distinguishable). Several of these molars corresponded to older representatives (2-5 annuli). The molars that had almost completely developed roots (RDG III) and were slightly worn (DWG I; visible under the stereomicroscope) showed a distinguishable dentine-cement interface and an annulus. Even in molars with poorly developed roots, a thin cement annulus was identifiable (the outermost dark band may be absent).

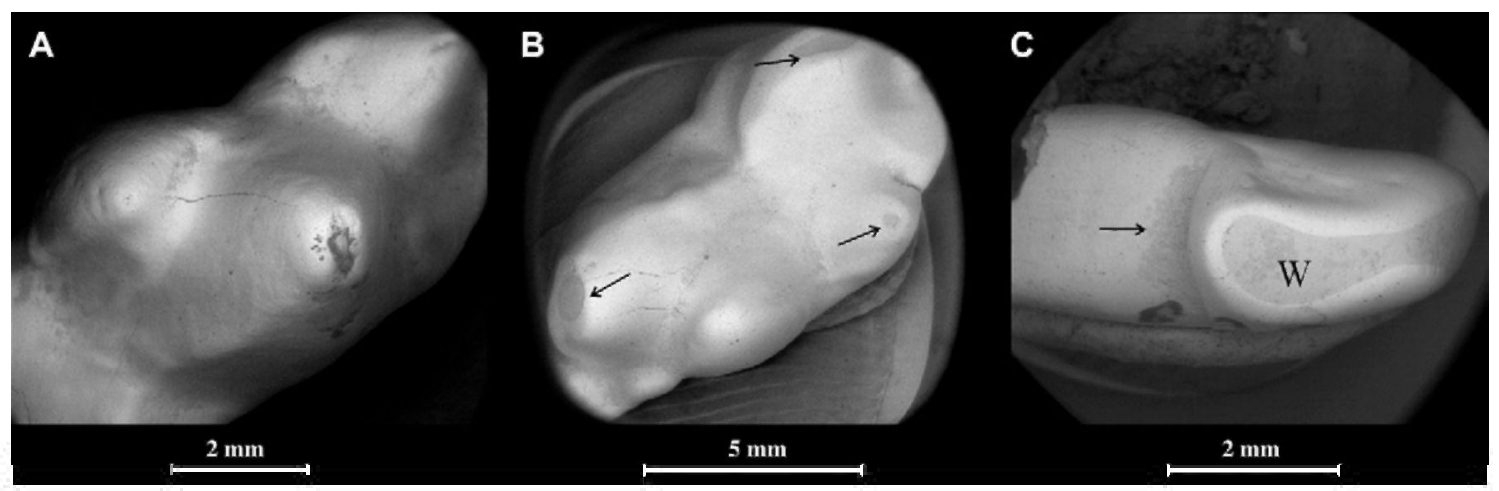

Fig. 4. ESEM images of some selected elements of the decidual dentition: (A) unworn dp4 dex. We interpret that the small "crater" on the protoconid tip is a default of enamel growth. (B) Heavily worn dp4 sin. Arrows indicate abraded zones. (C) Very worn id 2 dex. Arrow indicates the abraded crown cervix, and (W) indicates enamel worn out in the crown. 
Table 2

Number of worn and unworn lower decidual carnassials (dp4) of Ursus spelaeus from the Amutxate Cave (Navarra, Spain)

\begin{tabular}{cccc}
\hline & Number & Unworn & Worn \\
\hline dp4 & $316(145 \mathrm{~s}, 160 \mathrm{~d}, 11 \mathrm{i})$ & 169 & 143 \\
\hline
\end{tabular}

s: left; d: right; i: indeterminate.

For a more accurate age determination, some researchers increase the age determined by annuli counting by a number of months. They do this because during the first four months of a cub's life in the den, no cement production occurs in the permanent molars, as Rausch (1961) observed in nonhibernating black bears in zoos. Wiley (1974) added 0.75 years to the total counted annuli in specimens of black bear from North America (measured on canines and premolars). Kurtén (1958) added 0.4 years for the cave bear from Drachenhöle (Mixnitz, Austria), and later he added 0.5 years for the cave bear from Odessa (Kurtén, 1976). In black bears, Stoneberg and Jonkel (1966) added 1.0 year to the total counted rings and identified the white band as summer cement growth and correlated the dark bands to a winter (end of fall) cement increment. Craighead and colleagues (1970) added five months to the age calculated from the annuli count, confirming that the dark layer was formed during the end of fall/beginning of winter. Here we added 0.4 years to the annuli counted.

MDG I and MDG II representatives corresponded to firstwinter cubs (Fig. 6). The smaller ones belonged to newborn bears that died in the perinatal period, whereas the largest ones were from newborn bears that died just before leaving the den. Their death could be linked to a number of causes: the mother's death or abandonment of the litter, starvation caused by intra-litter competition, and so on.

Specimens classified in MDG III (Fig. 6) were from second-winter cubs that re-entered the cave before weaning. McLellan (1994) and Swanson et al. (1994) concluded that $40 \%$ of the offspring separated from their mothers as yearlings (MDG III) and the rest as two-year-olds (Craighead et al., 1995). Weaning probably occurred after a size threshold had been reached (Dahle and Swenson, 2002, 2003). Furthermore, nitrogen isotopic values suggested to Lidén and Angerbjörn (1999) that second-winter cave bear cubs were unweaned.

Subadult representatives (MDG IV) (Fig. 6) did not account for a large component of the total spectrum of bears that died during hibernation in Amutxate cave; this is consistent with the findings in most Iberian cave bear locations (see Torres, 1984). These subadults had probably just surpassed the weaning threshold.

Table 3

Frequencies of the wear stages of lower premolars and molars of Ursus spelaeus specimens from the Amutxate Cave (Navarra, Spain)

\begin{tabular}{lcccc}
\hline Wear group & P4 & M1 & M2 & M3 \\
& $n=133$ & $n=155$ & $n=166$ & $n=110$ \\
\hline DWG I & 80 & 64 & 72 & 69 \\
DWG II & 17 & 8 & 8 & 16 \\
DWG III & 1 & 3 & 8 & 13 \\
DWG IV & 2 & 25 & 12 & 2 \\
\hline
\end{tabular}

Table 4

Frequencies of root development groups $(30,50,90$, and $100 \%)$ of the lower premolars and molars of Ursus spelaeus specimens from the Amutxate Cave (Navarra, Spain). Re-calculated frequencies for specimens without fully developed roots (apices still open) are in italics

\begin{tabular}{lccccc}
\hline & Root length (\%) & P4 & M1 & M2 & M3 \\
& & $(n=123$ & $n=145$ & $n=133$ & $n=107$ \\
& & $28(49)$ & $1(1)$ & $8(13)$ & $51(90)$ \\
& $<30$ & $23(39)$ & $7(12)$ & $48(81)$ & $5(8)$ \\
RDG I & 50 & $7(12)$ & $48(87)$ & $4(6)$ & $1(2)$ \\
RDG II & 90 & 42 & 44 & 40 & 43 \\
RDG III & 100 & \multicolumn{3}{c}{} \\
RDG IV & & & & &
\end{tabular}

The life expectancy of MDG V representatives (Fig. 6) was not high compared with that of extant living bears (Table 1). After reaching the age of 13.4 years (13 annuli), representatives of this developmental group showed a marked decline in life expectancy. This decrease was probably linked to their extreme dental wear and the related undernourishment, which led to death by starvation during hibernation.

Table 5

Analysis of the wear, root development, and cement incremental layers (annuli) from a set of selected M1 samples from Amutxate cave

\begin{tabular}{|c|c|c|c|c|}
\hline Sample & $\begin{array}{l}\text { Wear } \\
\text { DWG }\end{array}$ & $\begin{array}{l}\text { Root } \\
\text { RDG }\end{array}$ & $\begin{array}{c}\text { EM } \\
\text { cement }\end{array}$ & $\begin{array}{l}\text { ESEM } \\
\text { cement }\end{array}$ \\
\hline AX6775 & I & II & 0 & $\begin{array}{l}\text { D/C interface visible. } \\
\text { Halus in the } \\
\text { outermost dentine area. }\end{array}$ \\
\hline AX296 & I & II & 1 & 1 annulus. \\
\hline $\mathrm{AX} 417$ & I & II & 1 & 1 annulus. \\
\hline AX6563 & I & II & 0 & 1 annulus; damaged. \\
\hline AX3039 & I & II & 0 & 1 annulus; doubtful. \\
\hline AX6172 & I & II-III & 1 & $\begin{array}{l}1 \text { annulus; } \mathrm{D} / \mathrm{C} \\
\text { interface very visible. }\end{array}$ \\
\hline AX6780 & I & II-III & 1 & 1 annulus \\
\hline AX6596 & I & II-III & $?$ & $\begin{array}{l}\text { D/C interface very } \\
\text { visible. }\end{array}$ \\
\hline $\mathrm{AX} 3474$ & I & III & 0 & 1 annulus. \\
\hline AX1298 & I & III & 0 & 1 annulus. \\
\hline AX8010 & I & III & $?$ & $\begin{array}{l}\text { D/C interface visible; } \\
\text { cement bands broken. }\end{array}$ \\
\hline AX3919 & I & III & 1 & Unobservable. \\
\hline AX3043 & I & III & 1 & 1 annulus. \\
\hline $\mathrm{AX} 3562$ & I & III & 1 & $\begin{array}{l}1 \text { annulus; } \mathrm{D} / \mathrm{C} \\
\text { interface very visible. }\end{array}$ \\
\hline AX7384 & I & III & 1 & $\mathrm{D} / \mathrm{C}$ interface visible. \\
\hline AX8351 & I & III & 0 & Doubtful. \\
\hline AX6696 & I & IV & 1 & \\
\hline AX891 & I & IV & 1 & $\begin{array}{l}1 \text { annulus; } \mathrm{D} / \mathrm{C} \\
\text { interface clearly } \\
\text { visible. }\end{array}$ \\
\hline $\mathrm{AX} 3641$ & I & IV & 1 & \\
\hline AX8152 & II & IV & 1 & $\begin{array}{l}\text { D/C interface very } \\
\text { visible. }\end{array}$ \\
\hline AX7089 & II & IV & 2 & \\
\hline $\mathrm{AX} 4173$ & II & IV & 5 & \\
\hline $\mathrm{AX} 7242$ & IV & IV & 10 & \\
\hline $\mathrm{AX} 4304$ & IV & IV & 17 & \\
\hline AX7380 & IV & IV & 13 & \\
\hline AX1-2 & IV & IV & 14 & 13 annuli. \\
\hline AX349 & IV & IV & 12 & \\
\hline $\mathrm{AX} 3536$ & IV & IV & 19 & \\
\hline
\end{tabular}




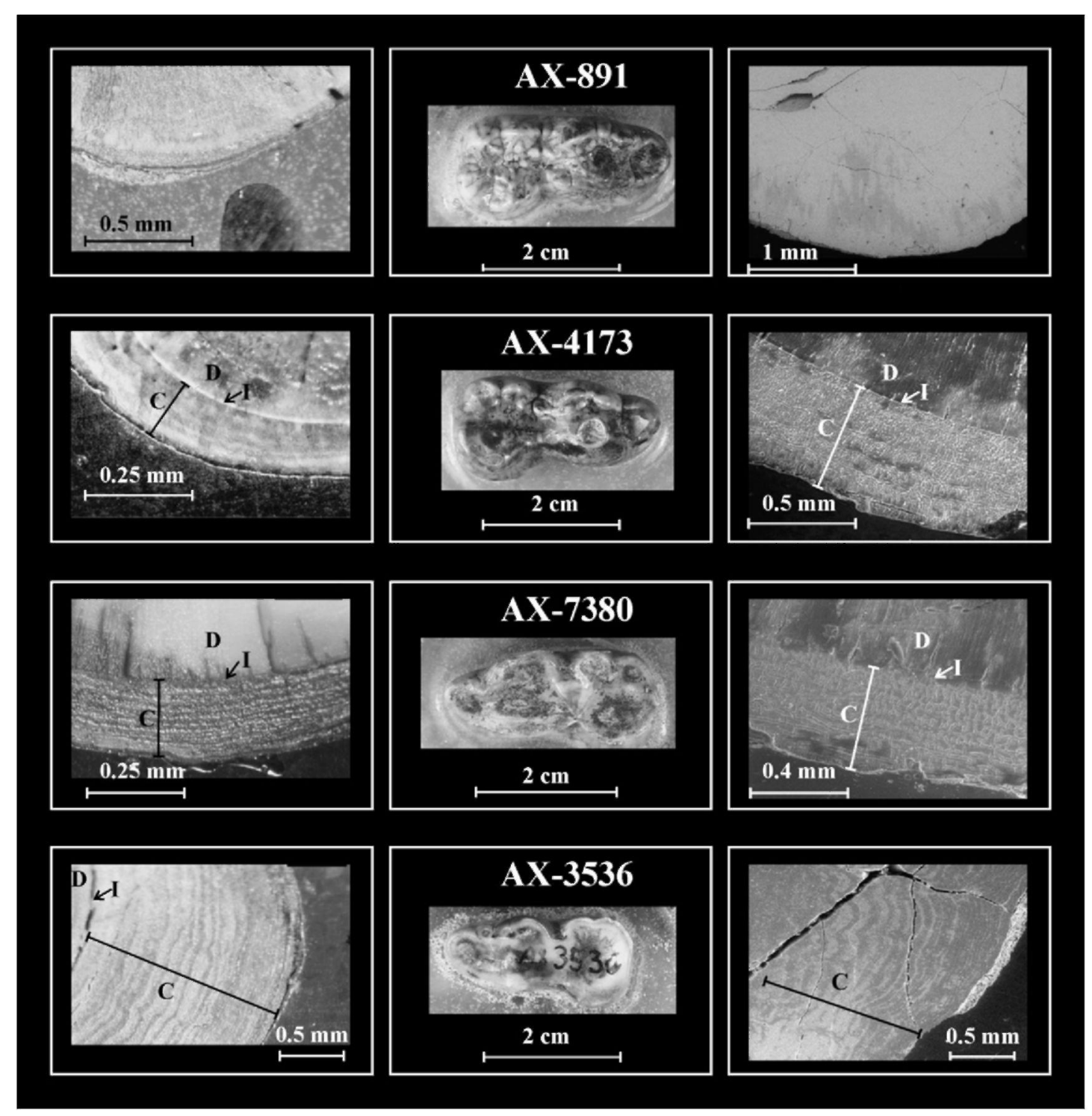

Fig. 5. Selected samples of lower carnassial root sections. On the left there are reflection photos; in the central column photos from the occlusal view of the crown appear. The right column shows ESEM images. AX-891 is a right lower molar without traces of wear but closed roots (DWG I; RDG IV) and a partially developed annulus can be observed. AX-4173 corresponds to a right first lower molar with the tips of the cusps worn and closed roots (DWG II; RDG IV). Five annuli can be observed. AX-7380 is a left first lower molar with deeply worn crown and closed roots (DWG IV; RDG IV). Thirteen annuli were identified. AX-3536 is a right first lower molar with enamel totally abraded and closed roots (DWG IV; RDG IV). Nineteen annuli are observed.

\section{Ontogenetic development of the mandible}

Descriptions of selected specimens from the mandible development groups (MDGs) are shown in Table 6. The table includes samples from other hibernating bear species, $U$. deningeri von Reichenau and $U$. arctos Linnaeus. Figures 7 and 8 show a number of selected photos and radiographs.

MDG I and MDG II mandibles are uncommon. Eheremberg (1931) reported a complete mandible of a newborn cave bear ca. $50 \mathrm{~mm}$ long (Taf. CXIX), and Debeljak (1996b) published photos of several mandibles of newborn cave bears with estimated lengths between 45 and $85 \mathrm{~mm}$. One of these, with an estimated age of two to three months, showed deciduous dentition (lost) fully emerged with still non-erupted M1 and P4 crowns.
In our study, all MDG I and MDG II mandibles had thin cortices of low density, and the bone surface texture was rough and porous. This texture appears when the pre-formed cartilaginous elements are replaced by bony tissue during endochondral ossification (Fig. 3A).

The age of MDG I mandibles can be interpreted through modern brown bear ontogeny. According to Pohle (1923), a three-month-old brown bear mandible was about $85 \mathrm{~mm}$ long, with the alveoli of the deciduous dentition and the germs of the three permanent lower molars (prealveoli) present. Couturier (1954) included radiographs of a wild brown bear (PI $\mathrm{XX}$ ), estimated to be two months old. Its mandible was $100 \mathrm{~mm}$ long, the complete deciduous dentition was in place, and the lower carnassial (M1) was starting to erupt (50\% of the root length developed). Dittrich (1960, Abb. 1, 2, p. 60) 


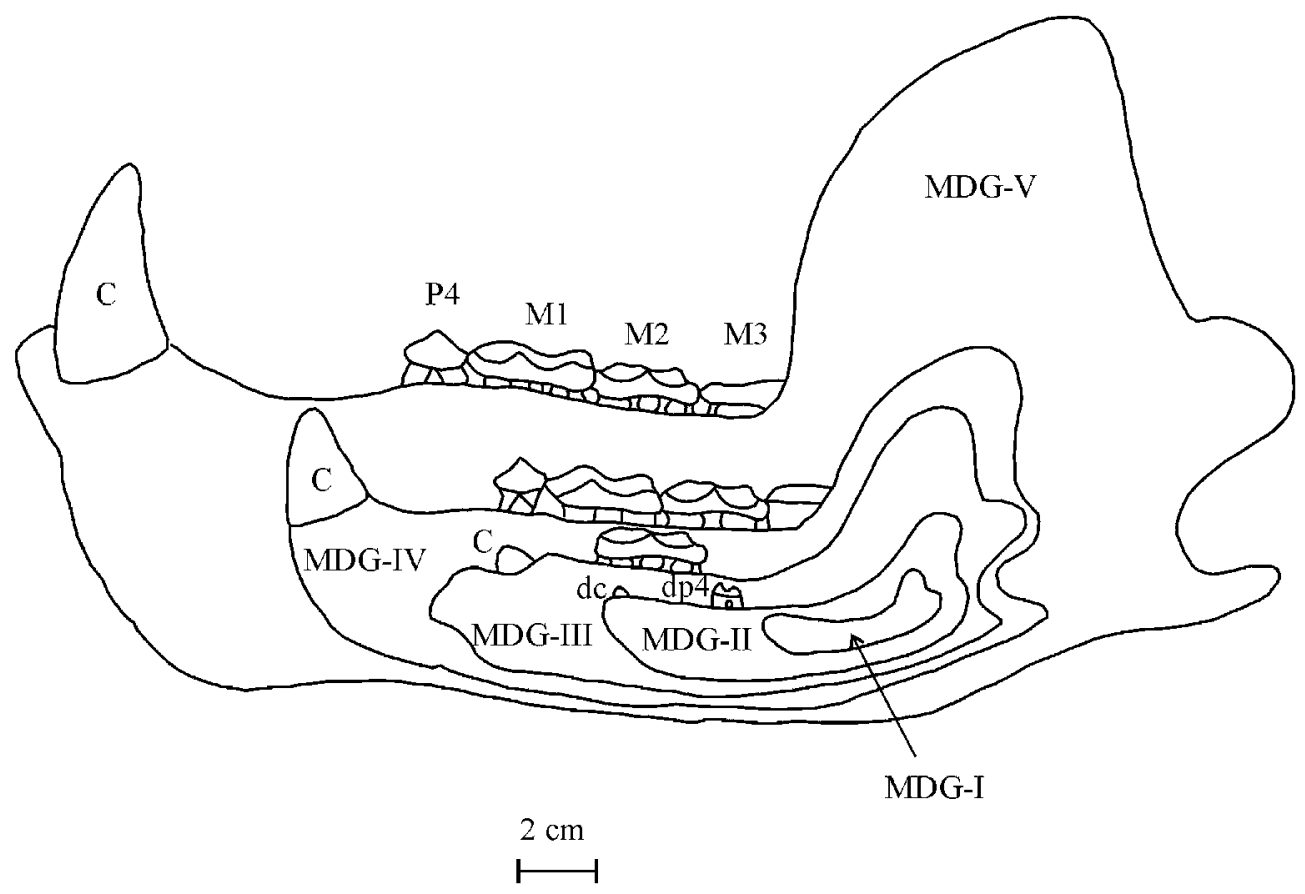

Fig. 6. Draft showing the ontogenetic development size groups of the cave bear mandibles recovered in Amutxate cave. This graph can be applied to any excavated cave bear site. Because complete newborn mandibles were not found for the MDG I group, we used an $x$-ray image from a newborn brown bear ( $U$. arctos), published by Eheremberg (1931).

published drawings from a radiograph of the dental development of a three-day-old brown bear showing an unerupted deciduous dentition consisting of enamel caps.

We studied two $U$. arctos mandibles from Saldarrañao cave (Espinosa de los Monteros, Burgos); the most complete, D1 [Fig. 7 (left)], had lost all the deciduous teeth with the exception of dp4, which showed closed roots and no occlusal wear. The germs of I2 and M1 were clearly visible along with the alveoli of M2 and M3 germs. The smaller mandible, D2 [Fig. 7 (left)], had lost its dp4, and the pre-alveolar openings on the mandibular corpus were very narrow (M1) or absent (M2).

Mandibles corresponding to MDG III are quite common in many locations: El Reguerillo, Madrid, Spain (Torres, 1974); Drachenhöle, Mixnitz, Austria (Eheremberg, 1931); Divje babe I, Slovenia (Debeljak, 1996b); Amutxate cave, Navarra, Spain (this paper); among many others. In our study, these mandibles showed a total length of between 140 and $180 \mathrm{~mm}$ (some are slightly damaged at the condylar zone and their total length was estimated). These mandibles show unerupted canines, partially erupted/unerupted P4s (RDG III), erupted M1s (RDG III), unerupted M2s (RDG II), and unerupted M3s (RDG I). According to Eheremberg (1931) and Kurtén (1976), mandibles with the above features correspond to one-year-old bears, in agreement with the age attribution of Andrews and Turner (1992) on the basis of permanent cheek teeth wear stages. According to Debeljak's (1996b) interpretation, these mandibles correspond to bear cubs aged 5 to 7.5 months. It is noticeable that some of the mandibles of Divje babe I (Debeljak, 1996b) are slightly smaller (20 mm shorter) than those from El Reguerillo and Drachenhöle caves. In the material found in Amutxate cave, similar size differences between mandibles with identical dental eruption stages were observed. We hypothesize that these differences, which appeared not only in cubs but in newborn cave bears from other sites [e.g., Troskaeta cave, Spain (Torres et al., 1991)], reflected sexual dimorphism.

Age attribution to MDG IV and MDG V was not problematic. Mandibles in these groups belonged to immature and mature bears. However, cement incremental layer counts were required to establish their probable age at death. To solve this problem, we assumed that the eruption intervals in the brown bear could be extrapolated to the cave bear. As shown in Figure 9, at the age of five months brown bear cubs show the breakthrough of the upper and lower first permanent molars, but dp4 still remains below the gum surface. According to Pohle (1923), in the polar bear (U. maritimus Phipps) there is a marked delay in the eruption of several elements of the permanent dentition, which is consistent with Couturier's (1954) observations on brown bear cubs from the Pyrenees.

Using these correspondences, in February, a month and a half after birth (mid-January), the deciduous lower carnassial (dp4) of cave bears was fully erupted. All the milk dentition was fully erupted at the age of three months (mid-April) or even slightly later (late April). These eruptions occurred close to the end of the hibernation period when newborns would abandon the den. The first lower carnassial began to break through the gums at the age of four and a half months (mid-May) when newborns had abandoned the den. At the age of eight months (mid-September or the beginning of October), the lower milk carnassial (dp4) fell 
Table 6

Description through direct observation and x-ray analysis of selected mandibles of Ursus spelaeus from Amutxate cave (AX) and La Lucia cave (LU). The description of a mandible of Ursus deningeri from Cueva Nueva (Pedraza, Spain) and two mandibles of Ursus arctos from Saldarrañao cave (Espinosa de los Monteros, Spain) have been added for comparative purposes

\begin{tabular}{lll}
\hline Reference species & Direct observation & X-ray and cement band counting (on M1) \\
\hline AX754 U. spelaeus MDG V & Complete left mandible of a & The root apices are closed. Root canals \\
male. M1 and M2 deeply worn & are largely closed. Marked interdental wear.
\end{tabular}

male. M1 and M2 deeply worn

(Group IV). In M3 more than

$50 \%$ of the enamel still remains

(Group III). P4 with wear traces

in the lower crest of the protoconid.

$C$ with profound wear notches at its

tip and on its labial side.

AX4522 U. spelaeus MDG V

AX3050 U. spelaeus MDG V

\section{AX2913 MDG V}

AX2237 U. spelaeus MDG IV

AX3852 U. spelaeus MDG IV

AX1014 U. spelaeus MDG IV

AX3238U. spelaeus MDG III
Right mandible of a big male. The M1 was avulsioned in vivo

due to the development of a necrotic abscess. M1 and M2 show

some wear (Group III and II, respectively).

Due to the lack of

the first lower molar there is some

wear on the labial side of

the talonid of the $\mathbf{P} 4$. Canine unworn.

Left mandible of a male. The vertical branch is lacking. P4 (taurodontic) was lost in vivo. M1 is deeply worn (Group IV); M2 and M3 are moderately worn (Group III and II). Canine broken during the animal's life but a polished stump remains where a $2 \mathrm{~mm}$ diameter dentinal channel crops out.

Right mandible of a female. The ramus ascendentis and the condyle are damaged (gnawed?). M1 and M2 are strongly worn (group IV); M3 is worn (Group II). P4 shows traces of wear in the protoconid and paraconid tips. The canine tip is blunted due to wear.

Left mandible of an immature female. The ramus ascendentis and the condyle lack. All premolar and molars are unworn (Group I). M1 shows wear traces.

Fragment of right mandible probably from a male. The M1 shows traces of wear; P4, M2, and M3 are unworn. The presence of scratches suggests that the mandibular damage was due to gnawing.

Left mandible from a young female. The ramus ascendentis and the condyle lack. Canines, premolars (taurodontic), and molars are completely erupted. In some areas of the M1 the typical enamel glace looks burnished.

Almost complete (ramus ascendentis broken) left mandible of a yearling. Third incisor, premolar, and second molar still unerupted inside their alveoli. The first lower molar was lost after fully erupting; the third lower molar fell out from its vertical alveolus behind. It is possible to see a vestigial alveolus of the deciduous molar (dp4).
The root apices are closed. M1 alveoli resorbed. The canals of the roots are largely closed. Slight interdental wear. The infectious process that affected M1 also affected the posterior root of $\mathbf{P} 4$.

The apices of the roots were totally closed. The P4's falling out was due to a teratological process, and the anterior root of the M1 shows an anomalous morphology. Marked interdentary wear facets do appear between M3-M2 and M2-M1. 18 complete (double) annuli can be counted.

The root apices are closed and the root canals are largely closed. Marked interdental wear is absent.

A minimum number of 15 double annuli can be distinguished.

Apices of the roots are closed. Four light bands and three dark bands are counted ( 3,5 double annuli).

All the root apices are closed. Large pulp cavities are open. The M3 seems to be loosely attached to its alveolus. Four light bands and three dark bands are counted (3.5 double annuli).

P4 roots fused. All roots show their apices closed. Root canals and pulp cavities are very large. $\mathrm{P} 4$ and $\mathrm{M} 1$ are implanted in a shallower position than M2 and M3. Two double annuli (two light bands and two dark bands) have been counted.

In the $\mathbf{P} 4$ the protoconid was pointing up while the talonid was largely inside the mandible in such a way that the dp4, with resorbed roots, could have remained fixed at the gum tissue for some time. The germs of the $\mathrm{I} 3$ and $\mathrm{C}$ and $\mathrm{M} 2$ are visible. The M2 roots are $50 \%$ developed. 
Table 6 (continued)

\begin{tabular}{lll}
\hline Reference species & Direct observation & X-ray and cement band counting (on M1) \\
\hline AX7582 U. spelaeus MDG III & Almost complete (ramus ascendentis broken) & According to the alveoli development, \\
& left mandible of a yearling. M2 unerupted. & the roots of the M1 reached almost total \\
The P4 was lost but their roots were not fully & development while the roots of the M2, still \\
& in place, are 50\% developed. The germ & of the crown of the C does not show any root \\
M3 fell out from its alveolus behind the & ramus ascendentis. The C germ remains at & development.
\end{tabular}

LU185 U. spelaeus MDG III

AX7671 U. spelaeus MDG III

NU $U$. deningeri MDG III

D1 $U$. arctos MDG II

D2 U. arctos MDG II

AX3104 U. spelaeus MDG II its alveolus without any trace of root.

Complete right mandible of a yearling from La Lucia cave (dated to $45 \mathrm{ka} \mathrm{BP}$, Torres et al., 2002). The I3 has partially erupted and the I2 and $\mathrm{C}$ are visible despite not being erupted. The M1 has fallen out but its roots were almost completely developed. The M2 and M3 were unerupted, and the M3 lay vertical behind the ramus ascendentis.

Fragment of right mandible of a yearling. Only the $\mathrm{M} 1$ remains in place (it can be easily removed manually). The depth of the alveoli of the P4 and M2 indicate that they had not yet erupted. The $C$ germ is in place and unerupted.

Almost complete right mandible of Ursus deningeri from Cueva Nueva (Pedraza, Spain). A lower incisor remains unerupted as does the germ of the $\mathrm{C}$. The alveoli of the absent premolars and molars remain. The tilt backwards is typical of $U$. deningeri.

Complete left mandible of a first-winter bear. The unworn $(\mathrm{dp} 4)$ remains and the alveoli of the $\mathrm{id} 1, \mathrm{id} 2, \mathrm{id} 3, \mathrm{~cd}, \mathrm{dp} 1$, and $\mathrm{dp} 2$ are visible. The germs of M1 and M2 are visible through openings at the alveolar border. The M3 germ is lost.

Almost complete left mandible of a first-winter representative from Saldarrañao Cave (Espinosa de los Monteros, Spain). Its ontogenetic development (smaller size, lack of opening over the M2 germ, and smaller bone thickness) reveals that this cub died before leaving the cave. All the alveoli of the elements of the decidual dentition are visible and, through openings at the alveolar order, reveal the presence of the germs of the M1 and M2. The germ of the M3 was lost. The mandibular body is a simple bony shell.

Fragment of left mandible of a first-winter cave bear representative found in Amutxate cave. The germ of the M1 remains and the alveoli of the dp4 are observable along with the alveoli of the germs of some elements of the permanent dentition: C, P4, and M2. The mandibular body consists of a tiny shell, and the enamel of the germ of the first molar is very thin and dark brown colored.
The roots of the M2 are $50 \%$ developed.

Only the crown of the canine is fully developed. The distal root of the M1 is probably closed while the proximal one remains slightly open. The root canals and pulp cavities are very open.

$\mathrm{I} 3$ and $\mathrm{C}$ are visible, as are the incompletely developed alveoli of premolars and molars.

I1, I2, I3, C, P4, M1, and M2 germs are visible. M3 is lost but its alveolus remains. The dp4 is at its place and its long, penetrating, and fully preserved roots are forked, literally astride the protoconid of the $\mathrm{P} 4$. The density of the enamel of the germs of the permanent dentition seems to be lower than that of the decidual carnassial.

It is possible to observe the germ of the M1 $(0 \%$ root development) as well as the germs of the permanent canine and at least two incisors. The low density of the bone shell is clearly observable.

The $\mathrm{x}$-ray shows the lack of development of the permanent carnassial roots and the low density of the enamel. out. In the polar bear, the dp4 remains in situ until the tenth month of age (mid-November or December) and falls out during hibernation. On the basis of the chronology of teeth eruption shown by $U$. arctos, $U$. spelaeus mandibles with fully emerged M1s, in stage MDG III, did not correspond to "spring" bears but to older ones (yearlings). We should note that if the climate were colder the actual time of year of eruption might be quite different. 

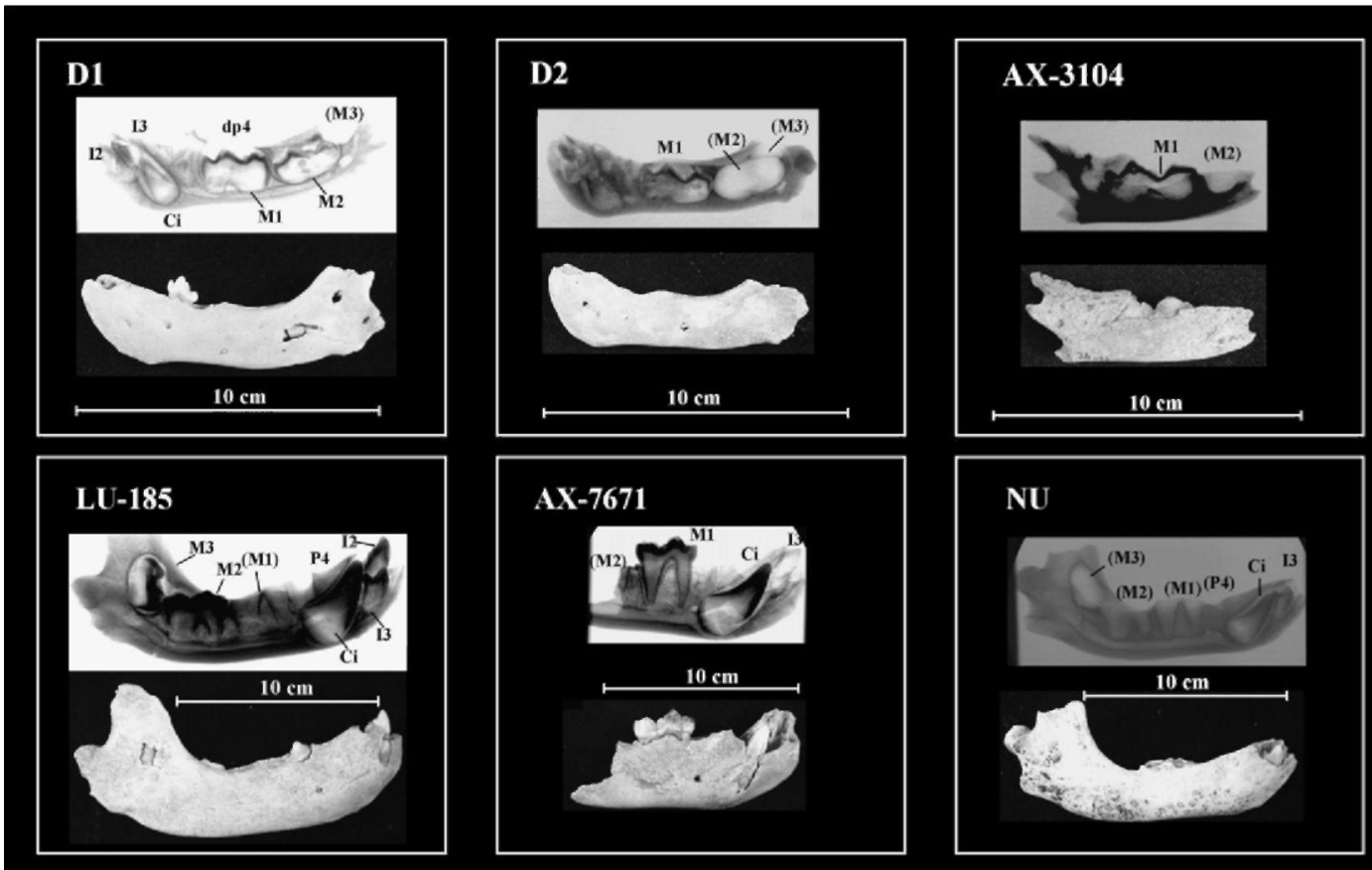

Fig. 7. Photos (external views) and x-ray analysis of mandibles with distinct stages of ontogenetic development. DWG II: D1, left mandible of $U$. arctos from Saldarrañao cave; D2, left mandible of $U$. arctos from Saldarrañao cave; AX-3104, right mandible of $U$. spelaeus from Amutxate cave. MDG III: LU-185, right mandible of $U$. spelaeus from La Lucia cave; AX-7671, left mandible of $U$. spelaeus from Amutxate cave; NU, right mandible of $U$. deningeri from Cueva Nueva.
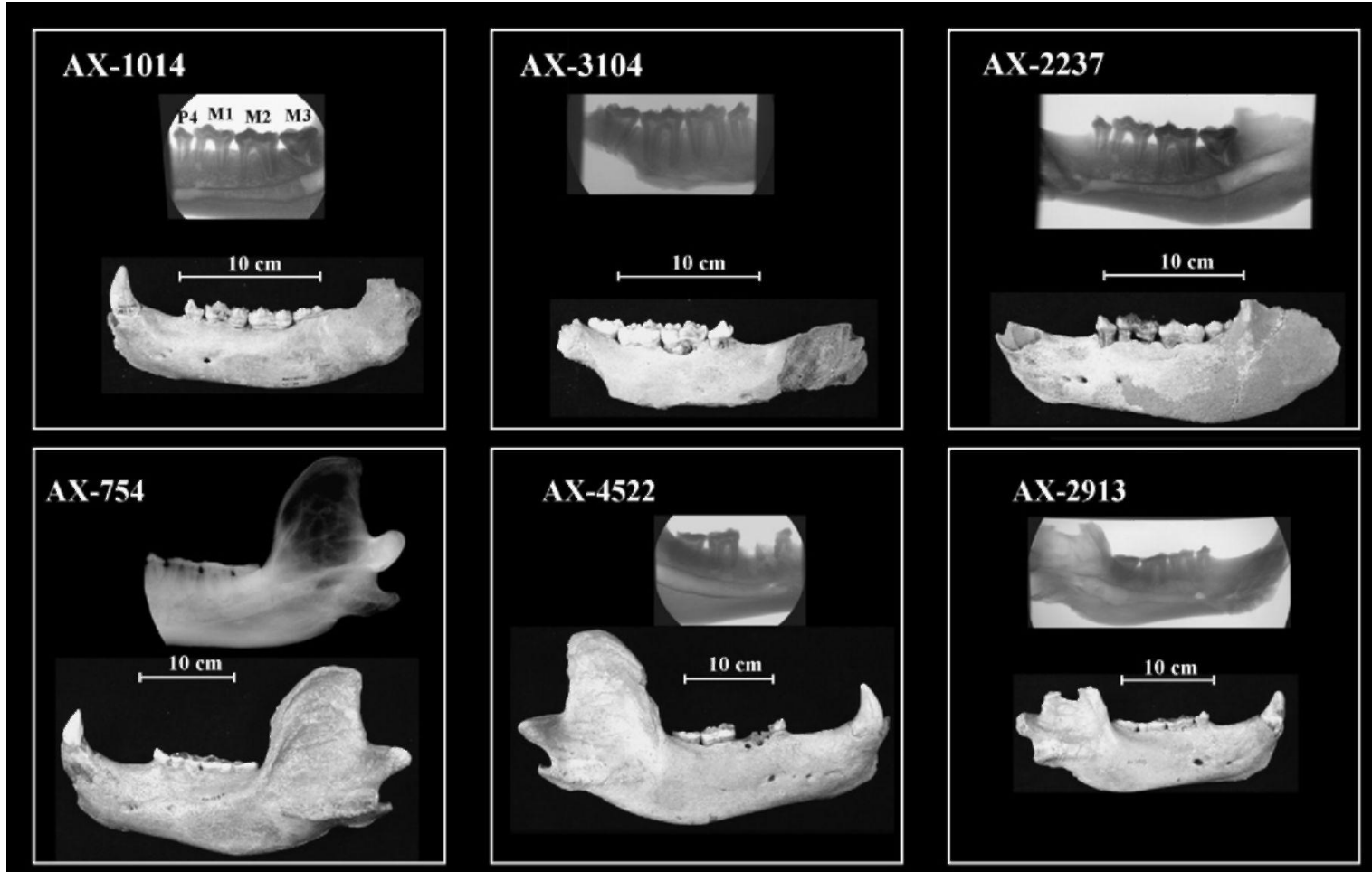

Fig. 8. Photos (external views) and x-ray analysis of mandibles with distinct stages of ontogenetic development. MDG IV: AX-1014, left mandible of $U$. spelaeus from Amutxate cave; AX-3104, right mandible of $U$. spelaeus from Amutxate cave; AX- 2237, left mandible of U. spelaeus from Amutxate cave. MDG V: AX754, left mandible of $U$. spelaeus from Amutxate cave; $\mathrm{AX}-4522$, right mandible of $U$. spelaeus from Amutxate cave; AX-2913, right mandible of $U$. spelaeus from Amutxate cave. 


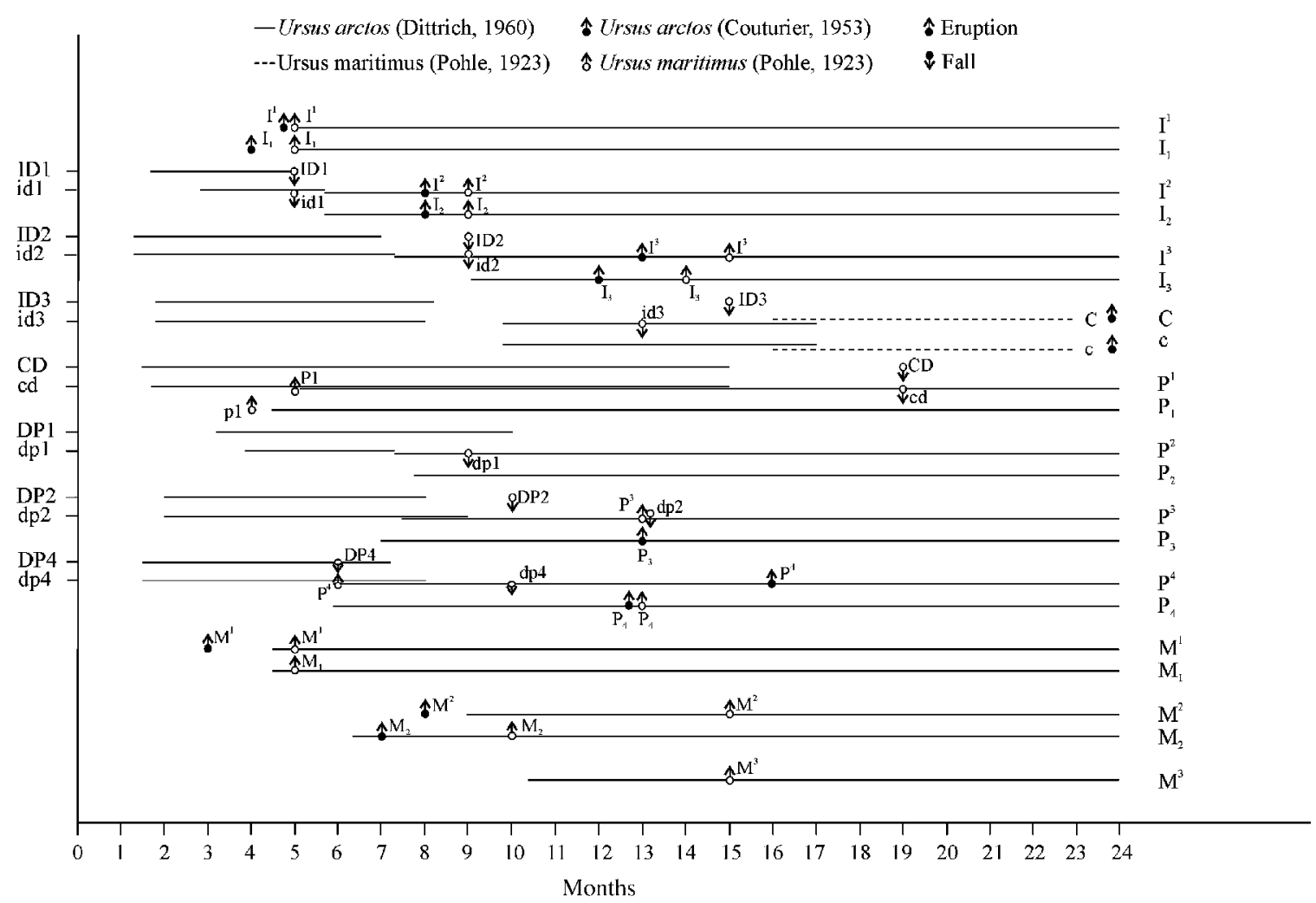

Fig. 9. Eruption of deciduous dentition elements and timing of fall and eruption of permanent dentition elements in living species of hibernating bears, following Dittrich (1960), Pohle (1923), and Couturier (1954). In deciduous dentition upper and lower cases indicate upper and lower dentition elements, respectively. In permanent dentition, superscript and subscript numbers indicate upper and lower elements, respectively.

\section{Conclusions}

The mortality rate of MDG I representatives from Amutxate cave is unknown. These bears could have died during the perinatal period or through spontaneous abortions. On the basis of our findings, we propose that the mortality rate in MDG II representatives was probably high. These specimens showed unworn deciduous teeth and died during the end of their first-winter probably due to undernourishment, disease, or maternal abandonment.

MDG III representatives died during their first complete hibernation (second-winter, 1.4 years), probably due to undernourishment. These cubs spent a complete spring/fall period outside the den with a mixed diet (milk and vegetables). These feeding habits produced visible dental wear of the deciduous teeth. Deciduous teeth with visible traces of wear and several degrees of root resorption belonged to this age group. The mortality rate among this group was probably high, as occurs in modern brown bears (30\%).

MDG IV representatives corresponded to independent subadults that did not reach sexual maturity (5 years) or had just reached this stage. Their mortality rate during hibernation was probably low, but they could be more easily hunted than adult bears.

MDG V adults showed marked wear (DWG IV). Pathological processes affecting the first lower molar alveoli were frequent due to diseases linked to feeding habits. Their early eruption and shallow implantation favored tooth avulsion in vivo. In some localities, avulsion affects more than $15 \%$ of mandibles (Torres, 1976).

In determining the continuity of cave bear inhabitation of Amutxate cave, we take the following into consideration:

1. According to ESR and AAR dating, Amutxate cave was inhabited by bears for about 9,000 years.

2. The excavated area $\left(40 \mathrm{~m}^{2}\right)$ accounts for $7 \%$ of the total "bear hall" area. The regular abundance of findings on the floor indicates that the density of findings from the excavated area can be extrapolated to the total.

3 . The number of M1 teeth from very old cave bear representatives (DWG IV and RDG IV) suggests that 22 individuals died at the age of 20 years. This represents an accumulated time span of 440 years, which, if extrapolated to the whole site, represents bear habitation of 7,000 years.

4. Nine young adults (M1 in stages DWG II, DWG III, and RDG I) died at the age of 5-7 years, which adds 45 years to the sampled area (7\%) and 700 years to the whole "bear hall."

These calculations must be interpreted in a conservative way if we consider that at least $15 \%$ of deeply worn M1s cannot be accounted for because of infected mandibles, in vivo avulsion, and diagenesis. Also, we cannot estimate the possible loss of teeth in stages MDG III and MDG IV from bears that never reentered the cave due to accidents or carnivore predation (Andrews and Turner, 1992). In conclusion, rapid bear 
abandonment of Amutxate cave after hibernation permitted its temporary use by hominids from the beginning of spring to the end of fall, but the presence of wandering bears-large males and zealous females with their litters-particularly during the mating period, were probably a threat to hominids. Given that the cave bear home range extends between 500 and $1,000 \mathrm{~km}^{2}$, and that large amounts of cave bear remains have been found in the vicinity of other caves (Troskaeta and Eulatz caves, see Fig. 1), hominid group expansion and exploitation of the environment was likely to be severely limited by cave bear activity.

The dramatic expansion of hominids during Upper Paleolithic times contributed to the extinction of the cave bear, as Grayson and Delpech (2003) postulated as the Kurtén's Response or man-mediated cave bear extinction.

\section{Acknowledgements}

The excavation campaigns were funded by the Departamento de Obras Públicas of the Diputación Foral de Navarra (C. Acaz) and the Museo Histórico Minero D. Felipe de Borbón y Grecia of the Madrid School of Mines. The excavation campaigns would not have been possible without the invaluable collaboration of the Satorrak Speleological Group. We thank the large number of enthusiastic students who worked very hard during the excavation campaigns and material study. The x-ray examinations were made by Dr. Ignacio Pastor from the University Hospital La Paz in Madrid. Dr. Casilda Ruiz from the Madrid School of Mines helped us with the microphotographs. Dr. Yolanda Fernández-Jalvo gave us access to the ESEM at the National Museum of Natural Science. ESEM images were obtained by Laura Tormo. We thank Professor Susan Antón and three anonymous reviewers for their helpful comments for the improvement of the manuscript.

\section{References}

Alt, G.L., 1983. Timing of parturition of black bears (Ursus americanus) in northeastern Pennsylvania. J. Mam. Res. 64, 305-307.

Amstrup, S.C., 1995. The polar bear - Ursus maritimus, biology, management and conservation. US Fish and Wildlife Report on Polar Bears, www.polar bearsinternational.org/amstrup-1-14.php.

Andrews, P., Turner, A., 1992. Life and death of the Westbury bears. Ann. Zool. Fenn. 28, 139-149.

Bächler, E., 1940. Das Alpine Paläolithikum der Schweiz. Monographien zurund Frughgeschichte del Schweiz II (5), 1-262.

Beaupré, G.S., Stevens, S.S., Carter, D.R., 2000. Mechanobiology in the development, maintenance, and degeneration of articular cartilage. J. Rehabil. Res. Dev. 37 (2), 145-152.

Bocherens, H., Fizet, M., Mariotti, A., 1990. Mise en evidence alimentaire vegetarian de l'ours des caverns (Ursus spelaeus) par la biogeochimie isotopique $(13 \mathrm{C}, 15 \mathrm{~N})$ du collagen des vertebrés fossiles. C. R. Acad. Sci. Paris 331, 1279-1284

Bocherens, H., Fizet, M., Mariotti, A., Lange-Brade, B., Vandermeesch, B., Borel, J.P., Bellon, G., 1991. Isotopic biogeochemistry (13C, 15N) of fossil vertebrate collagen: application to the study of a past food web including Neanderthal man. J. Hum. Evol. 20, 481-492.

Breuer, R., 1931. Zur anatomie, pathologie und histologie der eckzäne bei Ursus spelaeus. In: Abel, O., Kirle, G. (Eds.), Die Drachenhöle bei Mixnitz. Speläologische Monographien, Bd VII-VIII, pp. 581-610.
Clevenger, A.P., Purroy, F.J., 1991. Ecología del oso pardo en España. Monografías del Consejo Superior de Investigaciones Científicas, Madrid.

Couturier, M.J. (Ed.), 1954. L'Ours Brun. Grenoble.

Craighead, J.J., Craighead, F.C., McCutchen, H.E., 1970. Age determination of grizzly bears from fourth premolar tooth sections. J. Wildl. Manage. 34 (2), 353-363.

Craighead, J.J., Sumner, J.S., Mitchel, J.A., 1995. The Grizzly Bears of Yellowstone: Their Ecology in the Yellowstone Ecosystem, 1959-1992. Island Press, Washington DC.

Crombie, D.L., Espinosa, E., Carei, M.C., Igimi, H., Hofman, A.F., 1993. Ursodeoxycholic acid in the Ursidae: biliary bile acids of bears, pandas and related carnivores. J. Lipid Res. 34, 1911-1917.

Dahle, B., Swenson, J.E., 2002. Family break-up in brown bears: are young forced to leave. J. Mammal. 84 (2), 536-540.

Dahle, B., Swenson, J.E., 2003. Factors influencing length of maternal care in brown bears (Ursus arctos) and its effect on offspring. Behav. Ecol. Sociobiol. 54, 352-358.

Debeljak, I., 1996a. A sample preparation technique of cave bear teeth for age determination by cementum increments. Rev. Paléobiol. 15 (1), 105-108.

Debeljak, I., 1996b. Ontogenetic development of dentition in the cave bear. Geologija 39, 13-77.

Dittrich, L., 1960. Milschgebissentwicklung und Zahnwechsel beim Braunbären (Ursus arctos) und anderen Ursiden. Gegenbaurs Morphol. Jahrb. 101, $1-141$.

Eheremberg, K., 1931. Uber die ontogenische Entwicklung des Hölenbären. In: Abel, O., Kirle, G. (Eds.), Die Drachenhöle bei Mixnitz. Speläologische Monographien VII-VIII, pp. 624-710.

Ferguson, S.H., McLoughlin, P.D., 2000. Effects of energy availability, seasonality and geographic range on brown bear life history. Ecography 23, 193200.

Fernández-Mosquera, D., 1998. Isotopic biogeochemistry $\left(\delta^{13} \mathrm{C}, \delta^{15} \mathrm{~N}\right)$ of cave bear (Ursus spelaeus) from Cova Eiros Site, Lugo. Cad. Lab. Xeol. Laxe $23,237-249$.

Francillon-Vieillot, H., Buffrénil, V., Castanet, J., Géraudie, J., Meunier, F.J. Sise, J.Y., Zylberg, L., Ricqlés, A., 1990. Microstructure and mineralization of vertebrate skeletal tissues. In: Carter, J.G. (Ed.), Skeletal Biomineralization: Patterns, Processes and Evolutionary Trends, vol. I. Van Nostrand Reinhold, New York, pp. 471-530.

Gabori-Csánk, V., 1968. Observations sur l'habitat et le genre de vie in Dienes. In: Kretzoi, M., Krivan, P., Krolpp, E., Stieber, J. (Eds.), La Station du Paleolithique Mon (Hongrie). Akademici Kiado, Budapest, pp. 197-244.

Gargett, G., 1996. Cave Bears and Modern Human Origin. The Spatial Taphonomy of Pod Hradem Cave, Czech Republic. University Press of America, Maryland.

Grandal d'Anglade, A., 1993. Estudio paleontológico de los restos de Ursus spelaeus Rosenmüller-Heinroth 1794 (Mammalia, Carnivora Ursidae) de Cova Eirós (Triacastela, Lugo, NW de la Península Ibérica). M.S. Dissertation, A Coruña University, Spain.

Grandal d' Anglade, A., Vidal-Romaní, R., 1997. A population study on the cave bear (Ursus spelaeus Ros.-Hein.) from Cova Eiros (Triacastela, Galicia, Spain). Geobios 30 (5), 723-731.

Grayson, D.K., Delpech, F., 2003. Ungulates and the Middle-to-Upper Paleolithic transition at Grotte XVI (Dordogne France). J. Archeol. Sci. 30 (12), $1633-1648$.

Hitchcock, D., 2005. http://donsmaps.com/bear2.html.

Hillson, S., 1986. Teeth. Cambridge University Press, Cambridge.

Johnson, K.G., 1978. Den ecology of black bears (Ursus americanus) in the Great Smoky Mountains National Park. M.S. Dissertation, University of Tennessee.

Klevezal, G.A., Kleinenberg, S.E., 1967. Age Determination of Mammal from Annual Layers in Teeth and Bones. Israel Program for Scientific Translation, Jerusalem.

Koby, F., 1949. Le dimorphisme sexuel des canines d' Ursus arctos et d'Ursus spelaeus. Rev. Suisse Zool. 56, 675-687.

Koby, F., 1952. La dentition lacteale d' Ursus spelaeus. Rev. Suisse Zool. 59 (27), 511-541.

Kolenosky, G.B., 1990. Reproductive biology of black bears in east-central Ontario. Int. Conf. Bear Res. Manag. 8, 385-392. 
Kurtén, B., 1958. Life and death of the Pleistocene cave bear. Acta Zool. Fenn. 95, 1-59.

Kurtén, B., 1976. The Cave Bear Story. Columbia University Press, New York.

Lentfer, J.W., Miller, L.H., 1969. Big game investigations. Polar bear studies (Project Segiment Report, vol. 10 Federal Aid in Wildlife Restoration P. W-15-R-3 and W-17-1, Work Plans M and R). Alaska Dep. of Fish and Game, Div. of Game, Juneau.

Lidén, K., Angerbjörn, A., 1999. Dietary change and stable isotopes: a model of growth and dormancy in cave bears. Proc. R. Soc. Lond. B, Biol. Sci. $266,1779-1783$.

Lyman, C.P., Willis, J.S., Malan, A., Wang, L.C.H., 1982. Hibernation and Torpor in Mammals and Birds. Academic Press, New York.

McLellan, B., 1994. Density dependent population regulation in brown bears. In: Taylor, M. (Ed.), Density Dependent Population Regulation in Black, Brown and Polar Bears. Monographie Series International Association for Bear Resources and Management. Port City, Washington DC, pp. 15-25.

Mundy, K.R.D., Fuller, W.A., 1964. Age determination in the grizzly bear. J. Wildl. Manage. 28 (4), 863-866.

Musil, R., 1965. Die Bärenhole Pod Hradem: die entwicklung der Hölenbären im letzen glazial. Anthropos 18, 7-92.

Needham, K., 2000. Aspects of Reproduction and Cub Survival in a Hunted Population of Virginia Black Bears. M.S. Dissertation. Politechical Institute and State University of Virginia.

Nelson, R.A., Jones, J.D., Wahner, H.W., Mcgill, D.B., Code, C.F., 1975. Nitrogen metabolism in bears: urea metabolism in summer starvation and in winter sleep and role of urinary bladder in water and nitrogen conservation. Mayo Clin. Proc. 50, 141-146.

Osborn, J.W., 1981. Dental Anatomy and Embryology. A Companion to Dental Studies, vol. 1, Book 2. Blackwell, Oxford.

Pérez, P.J., González, O.T., Fraile, L., Torres, T., 1986. Paleopathological study of skeletal remains of ursids of the Pleistocene-Holocene of the Iberian Peninsula. Proceedings VIth European Meeting of Paleopathology, Madrid, pp. 257-260.

Pinto-Llona, A.C., Andrews, P.J., Etxebarría, F., 2005. Taphonomy and Palaeocology of Bears from the Quaternary of Cantabria, Spain. Fundación Oso de Asturias, Oviedo.

Pohle, H., 1923. Uber den Zahnwechsel der Bären. Zool. Anz. 55, 266-277.

Ramsay, M.A., Stirling, I., 1986. On the mating system of polar bears. Canadian J. Zool. 64, 214-251.

Rausch, R.L., 1961. Notes on the black bear Ursus americanus Pallas in Alaska with special reference to dentition and growth. Z. Säugetierkd. 26 (2), 77-107.

Scott, J.H., Symons, N.B.B., 1974. Introduction to Dental Anatomy. Churchill Livingstone, Edinburgh.

Soibelzon, L., Carlini, A., 2003. Deciduous teeth morphology of some tremarctines (Ursidae, Tremarctinae). Description, comparisons and possible phylogenetic implications. Ameghiniana 41 (2), 217-224
Stallibrass, S., 1982. The use of cement layers for absolute ageing of mammalian teeth: a selective review of the literature with suggestions for further studies and alternative applications. In: Wilson, B., Grigson, C., Paine, S. (Eds.), Ageing and Sexing Animal Bones from Archaeological Sites. BAR British Series, 109, pp. 109-126.

Stiner, M.C., 1998. Mortality analysis of Pleistocene bears and its paleoanthropological relevance. J. Hum. Evol. 34, 303-326.

Stirling, I., 1986. Research and management of polar bears, Ursus maritimus. Polar Record 23, 167-176.

Stirling, I., 1993. Bears, Majestic creatures of the Wild. Rodale Press, Emmaus, Pennsylvania

Stoneberg, R.P., Jonkel, C.J., 1966. Age determination of black bears by cementum layers. J. Wildl. Manage. 30 (2), 411-414.

Swanson, J.E., Sandegren, F., Bjärvall, A., Söderberg, A., Wabakken, P., Franzén, R., 1994. Size, trend, distribution and conservation of the brown bear Ursus arctos population in Sweden. Biol. Conserv. 70, 9-17.

Terzea, E., 1969. Nouvelles données sur la dentition lacteale de l' Ursus spelaeus. Proc. 4th Int. Congress Speleology in Yugoslavia 4-5, 383-389.

Torres, T., 1974. Estudio de la Cueva del Reguerillo. M.S. Dissertation, Politechnical University, Madrid.

Torres, T., 1976. Comparación entre algunos aspectos ecológicos de dos poblaciones de oso de las cavernas. Actas IV Congreso Nac. Espeleología Marbella, 104-125.

Torres, T., 1984. Ursidos del Pleistoceno-Holoceno de la Península Ibérica. Ph.D. Dissertation, Politechnical University, Madrid.

Torres, T., Cobo, R., Salazar, A., 1991. La población de oso de las cavernas (Ursus spelaeus parvilatipedis n.ssp.) de Troskaetáko Kobea (AtaunGuipuzcoa) (Campañas de excavación de 1987 y 1988). Munibe 43, $3-85$.

Torres, T., Ortiz, J.E., Lucini, M., Llamas, J.E., Canoira, L., 2002. The dating of fossil bear spanish sites through amino acid racemization: accomplishments and pending tretas. Atti Mus. Civ. Stor. Nat. Trieste 49, 107-114.

Tumarkin-Deratzian, A., 2003. Bone surface textures as ontogenetic indicators in extant and fossil Archosaurs: macroscopic and histological evaluations. Ph.D. Dissertation, University of Pennsylvania.

Uspenski, S.M., 1977. The polar bear and its conservation in the Soviet Artic. Central Laboratory on Nature Conservation. Ministry of Agriculture of the USSR, Moscow.

Ward, K., 1994. Grizzlies in the wild North. Word Press Inc., Minocqua, WI.

Wiley, C., 1974. Aging black bears from first premolar tooth sections. J. Wildl. Manage. 38 (1), 97-100.

Wilson, D.E., Ruff, S., 1999. The Smithsonian Book of North American Mammals. Smithsonian Institute Press, Washington DC.

Wimsatt, W.A., 1963. Delayed implantation in the Ursidae with particular reference to the black bear (Ursus americamus Pallas). In: Endersm (Ed.), Delayed Implantation. University of Chicago Press, Chicago, Illinois, pp. $49-76$. 